\title{
MORAL ASPECT REVIEW BY THEORY OF ROBERT M. ENTMAN IN THE CONSTRUCTION OF JOKO WIDODO HUGS MOMENTS WITH PRABOWO SUBIANTO IN THE ASIAN GAMES 2018 (News from Cnnindonesia.com Edition 29 - 30 August 2018)
}

\author{
Khanna Fajar Maulana and Jeanie Annissa \\ Universitas Budi Luhur, Indonesia \\ khannafajar19@gmail.com
}

\begin{abstract}
This research discuss about construction carried out by online media cnnindonesia.com to moment hug Joko Widodo with Prabowo Subianto in organizing the 2018 Asian Games in the pencak silat sport. This research aims to understand moral aspect review by theory of Robert M. Entman in the construction of Joko Widodo hugs moments with Prabowo Subianto in the Asian Games 2018 (news from Cnnindonesia.com edition 29 - 30 August 2018). The theory used is Robert M. Entman framing analysis, which is defining problems, estimating problems or sources of problems, making moral decisions and emphasizing solutions. The method used is a descriptive qualitative approach. The data collection technique uses secondary data which emphasizes research literature. The results of this research explain that cnnindonesia.com shows the issue and constructs the news of the moment to moral issues, Define Problems moral issues, namely the embrace of Jokowidodo and PrabowoSubianto together with Hanifan Yudani Kusumah martial arts athlete. Diagnosis Causes of hug moments can be an example for people to respect each other. Make Moral Judgment Hanifan Yudani Kusumah kissed the hands of Joko Widodo and Prabowo Subianto and embraced the two so they embraced tightly and asked their people to respect and respect each other. Treatment Recommendation hopes that the political contestation that takes place by the community can maintain mutual unity, togetherness and brotherhood.
\end{abstract}

Keywords: Construction, Moral, Framing Analysis, Online Media, Cnnindonesia.com

\section{INTRODUCTION}

Ahead of the presidential election many moments happened to the presidential and vice-presidential candidates which were reported through the media. The moment that occurred at the 2018 Asian Games branched off by Pencak Silat which was attended by Joko Widodo as President of the Republic of Indonesia and Prabowo Subianto as Chairman of the Executive Board of the Indonesian Pencak Silat Association (IPSI) and President of the International Pencak Silat Alliance (Pesilat).

Where Joko Widodo and Prabowo Subianto were sitting on the VIP bench, Hanifan Yudani Kusuma, a martial arts athlete fighting class C: $55 \mathrm{~kg}-60 \mathrm{~kg}$ from Indonesian who was competing in the final and succeeded in defeating Nguyen Thai Linh, a Vietnamese martial arts athlete. After that Hanifan won the Gold Medal and asked for the Indonesian red and white flag to be used as his cloak. After that, he celebrated by approaching President Joko Widodo and Prabowo Subianto on the VIP bench by kissing his hands and embracing the two leaders of President JokoWidodo and Prabowo Subianto to embrace him tightly. a moment that has a moral aspect in it and becomes an event or momentum between the two figures namely, Joko Widodo and Prabowo Subianto. Researchers are interested in examining the news of the moment because it has news value, namely the value of news prominance, the news value is measured by the magnitude of the event or its importance. Because this moment there was an important figure involved in it, namely Joko Widodo and Prabowo Subianto.

Some media highlighted the scenes or events of Joko Widodo's embrace with Prabowo Subianto, one of which was on the online media cnnindonesia.com where there were 2 news analyzed that led to moral issues, because it was interesting to be used as research material for researchers' thesis on how news construction was carried by online media cnnindonesia.com.

In reporting this moment there was a process by which the media constructed the news, one of which the researchers took cnnindonesia.com which was ranked twentieth in Indonesia sourced from Alexa.com.

Researchers determined that the date of August 29, 2018 was the moment when JokoWidodo's embrace with PrabowoSubianto and the researchers determined that the edition dated August 29 to August 30, 2018, was news published by cnnindonesia.com.

In cnnindonesia.com online media on 2 news analyzed, the researcher wants to know news construction related to moral issues on cnnindonesia.com about Joko Widodo's embrace moment with Prabowo Subianto using Robert M. Entman's framing analysis model theory because the analyzed news is Joko Widodo embrace moment with Prabowo 
Subianto at the 2018 Asian Games in online media cnnindonesia.com included two large dimensions and four elements of the concept that existed in Robert M. Entman's framing analysis theory.

Based on the background that has been presented by researchers, the formulation of the problem in research is "How tomoral aspect review by theory of Robert M. Entman in the construction of Joko Widodo hugs moments with Prabowo Subianto in the Asian Games 2018 (news from Cnnindonesia.com edition 29 - 30 August 2018)?"

\section{RESEARCH METHODS}

The research paradigm is a framework of thinking that explains how the researcher views the facts of social life and the researchers' treatment of science or theory. This constructionist paradigm is often referred to as the paradigm of production and the exchange of meaning. In this study, researchers used the constructivist paradigm to look at the way cnnindonesia.com's online media constructed their story about the news "The moment of embracing Joko Widodo with Prabowo Subianto."

In this study, researchers used a descriptive qualitative approach. Qualitative is defined as a research procedure that produces descriptive data in the form of written or spoken words from people and observable behavior. Researchers used a qualitative approach in the form of news data that the researchers had chosen namely, "moral aspect review by theory of Robert M. Entman in the construction of Joko Widodo hugs moments with Prabowo Subianto in the Asian Games 2018 (news from Cnnindonesia.com edition 29 - 30 August 2018). "

According to Sugiyono, the research method is basically a scientific way to obtain data with specific purposes and uses. In this research using Robert M. Entman's framing analysis method, because in the concept there are two big dimensions and four concept elements that influence the content of the news. Which is used to find out how online media cnnindonesia.com in constructing the news "Moment embrace JokoWidodo with PrabowoSubianto."

The research subjects used in this study are online media portals namely, cnnindonesia.com in the 29 - 30 August 2018 edition. In gathering information or news that wants to be investigated, researchers conduct search and sort news on cnnindonesia.com online media about the news "Moment of embrace Joko Widodo with Prabowo Subianto at the 2018 Asian Games."

The object of research used in this study was the news text "The moment of embracing Joko Widodo with Prabowo Subianto on the holding of the 2018 Asian Games" edition 29 - 30 August 2018 on the online media news portal cnnindonesia.com.

Data collection techniques in this study using primary data collection techniques, namely, non-participant observation by collecting and documenting news texts when embracing Joko Widodo with Prabowo Subianto on cnnindonesia.com edition 29 - 30 August 2018 and also this study uses in-depth interviews through Focus Group Discussion (FGD) consisting of 5 people to discuss moral issues that have been constructed and framed by online media cnnindonesia.com. Secondary data is, obtained by searching, collecting and documenting from various sources such as through the internet on the online media news portal cnnindonesia.com with 2 news that lead to moral aspects related to the news of the moment of Joko Widodo's embrace with Prabowo Subianto edition 29-30 August 2018, through library books used as reference material in research this.

The data analysis technique used in this research is the descriptive analysis approach, in this case the data the researcher describes is the news text "The moment of embracing Joko Widodo and Prabowo Subianto."

Validity is one of the strengths of qualitative research. To determine the validity in this study, the researcher focused on the source triangulation strategy, because this research is a qualitative study. Triangulation of authentic sources and also documentation studies in the form of online media on cnnindonesia.com about the news of the moment of Joko Widodo's embrace with Prabowo Subianto in organizing the 2018 Asian Games. So that it is expected to answer the research focus that has been determined, namely how to moral aspect review by theory of Robert M. Entman in the construction of Joko Widodo hugs moments with Prabowo Subianto in the Asian Games 2018 (news from Cnnindonesia.com edition 29 - 30 August 2018)?

\section{RESULTSAND DISCUSSION}

In this section, the researchers describe the results of the research and discussion using a framing analysis ofmoral aspect review by theory of Robert M. Entman in the construction of JokoWidodo hugs moments with Prabowo Subianto in the Asian Games 2018 (news from Cnnindonesia.com edition 29 - 30 August 2018). 
Table 1. News of Cnnindonesia.com

\begin{tabular}{ll}
\hline \multicolumn{1}{c}{ News Title } & \multicolumn{1}{c}{ Date/Time } \\
\hline Prabowo-Jokowi Holds Celebrate the Victory of & Wednesday, 29-August - 2018, \\
Pencak Silat & Time 16:58 WIB \\
\hline Zulhas Wants the People to Be Hugs Similar to & Thursday, 30-August - 2018, \\
Jokowi-Prabowo & Time 03:51 WIB \\
\hline
\end{tabular}

The researcher chose 2 news stories on cnnindonesia.com whose analysis used Robert M. Entman's framing analysis, which is a large two-dimensional approach namely; issue selection and highlighting aspects, and see by using the four elements of the concept of framing proposed by Robert M. Entman namely; Define Problems (defining the problem), Diagnose Chauses (estimating the problem or the source of the problem), Make Moral Judgment (making moral decisions) and Treatment Recommendation (emphasizing resolution) are used to understand how news construction is carried out by online media cnnindonesia.com.

On online media cnnindonesia.com presents issues and highlighting aspects, there are 6 words that often appear in the news cnnindonesia.com namely the word hug, moment, victory, hug, respect and hope. In the news cnnindonesia.com there are also 5 words that are easy to remember namely the words of victory, hugging, moment, respect and hope.

Cnnindonesia.com in highlighting aspects that want to be conveyed to a wide audience, using words and sentences to construct the news.

Table 2. Frame Cnnindonesia.com

\begin{tabular}{ll}
\hline Define Problems & $\begin{array}{l}\text { Moral issues, namely the moment of embracing Joko Widodo } \\
\text { and Prabowo Subianto with Hanifan Yudani Kusumah martial } \\
\text { arts athlete. }\end{array}$ \\
\hline Diagnose Causes & $\begin{array}{l}\text { The moment of hug can be an example for people to respect } \\
\text { each other. }\end{array}$ \\
\hline Make Moral Judgement & $\begin{array}{l}\text { Hanifan Yudani Kusumah kissed the hands of Joko Widodo } \\
\text { and Prabowo Subianto and embraced the two so they } \\
\text { embraced tightly and asked their people to respect and respect } \\
\text { each other. }\end{array}$ \\
\hline Treatment Recommendation & $\begin{array}{l}\text { Hoping that the ongoing political contestation of the } \\
\text { community can maintain mutual unity, togetherness and } \\
\text { brotherhood }\end{array}$ \\
\hline
\end{tabular}

Cnnindonesia.com views the news of Joko Widodo's embrace with Prabowo Subianto at the 2018 Asian Games, Define Moral Problems, namely the moment of embracing Joko Widodo and Prabowo Subianto together with Hanifan Yudani Kusumah martial arts athlete. Diagnosis Causes of hug moments can be an example for people to respect each other. Make Moral Judgment Hanifan Yudani Kusumah kissed the hands of Joko Widodo and Prabowo Subianto and embraced the two so they embraced tightly and asked their people to respect and respect each other. Treatment Recommendation hopes that the political contestation that takes place by the community can maintain mutual unity, togetherness and brotherhood.

Based on the results of in-depth interviews through Focus Group Discussion (FGD) consisting of 5 people aged between 21-24 years to discuss moral issues that have been constructed and framed by online media cnnindonesia.com, out of a total of 5 people interviewed based on 2 news cnnindonesia.com meant that both the news emphasized moral issues, namely the action of Hanifan Yudani Kusumah while celebrating by embracing Joko Widodo and Prabowo Subianto in one hug. The action carried out by Hanifan Yudani Kusumah to Joko Widodo and Prabowo Subianto is a good moral attitude such as respecting and appreciating which should be exemplified to the public that in the midst of the heat of the presidential election must have a good moral attitude by maintaining unity and brotherhood, even though different choices but must unite. Online media cnnindonesia.com publishes the news of the moment of the embrace of Joko Widodo and Prabowo Subianto before the 2019 presidential election so that the public can imitate the moral attitudes that existed at the moment of the embrace.

\section{CONCLUSION}

Based on the explanations in the previous chapters, this study is entitled "moral aspect review by theory of Robert M. Entman in the construction of Joko Widodo hugs moments with Prabowo Subianto in the Asian Games 2018 (news from Cnnindonesia.com edition 29 - 30 August 2018)" the results of research and discussion using Robert M. 
Entman's framing analysis which aims to produce moral aspect review by theory of Robert M. Entman in the construction of Joko Widodo hugs moments with Prabowo Subianto in the Asian Games 2018 (news from Cnnindonesia.com edition 29 - 30 August 2018). Researchers provide research results and discussion in chapter IV.

Cnnindonesia.com from all 2 news shows the issue and constructs the news of the moment to moral issues, Define Problems moral, namely the moment of embracing Joko Widodo and Prabowo Subianto together with Hanifan Yudani Kusumah martial arts athlete. Diagnosis Causes of hug moments can be an example for people to respect each other. Make Moral Judgment Hanifan Yudani Kusumah kissed the hands of Joko Widodo and Prabowo Subianto and embraced the two so they embraced tightly and asked their people to respect and respect each other. Treatment Recommendation hopes that the political contestation that takes place by the community can maintain mutual unity, togetherness and brotherhood.

The results of in-depth interviews through a Focus Group Discussion (FGD) consisting of 5 people aged between 21-24 years to discuss moral issues that have been constructed and framed by online media cnnindonesia.com, out of a total of 5 people interviewed based on 2 news cnnindonesia.com interpret that both news emphasize moral issues, namely the action of Hanifan Yudani Kusumah while celebrating by embracing Joko Widodo and Prabowo Subianto in one embrace. The action carried out by Hanifan Yudani Kusumah to Joko Widodo and Prabowo Subianto is a good moral attitude such as respecting and appreciating which should be exemplified to the public that in the midst of the heat of the presidential election must have a good moral attitude by maintaining unity and brotherhood, even though different choices but must unite. Online media cnnindonesia.com publishes the news of the moment of the embrace of Joko Widodo and Prabowo Subianto before the 2019 presidential election so that the public can imitate the moral attitudes that existed at the moment of the embrace.

\section{REFERENCES}

Cresswell, John W. (2016). Research Design PendekatanMetode Kualitatif, Kuantitatif dan Campuran. Yogyakarta: Pustaka Pelajar.

Eriyanto. (2018). Analisis Framing Konstruksi, Ideologi, dan Politik Media. Yogyakarta: LKiS Group.

Meleong, Lexy J. (2014). Metode Penelitian Kualitatif. Edisi Revisi, Bandung: PT Remaja Rosdakarya.

Noor, Juliansyah. (2011). Metodologi Penelitian: Skripsi, Tesis, Disertasi dan Karya Ilmiah. Jakarta: Kencana.

Sugiyono. (2018). Metode Penelitian Kuantitatif, Kualitatif dan R\&D. Bandung: Alfabeta.

http://www.cnnindonesia.com access on April 1st 2019, Time 11:14 WIB.

https://www.alexa.com/topsites/countries/ID access on October, 24th 2018, Time 20:22 WIB.

https:/www.cnnindonesia.com/nasional/20180829165430-20-325913/prabowo-jokowi-pelukan-rayakan-

kemenangan-pencak-silat access on April 1st 2019, Time 14:26 WIB.

https:/www.cnnindonesia.com/nasional/20180829203140-32-326013/zulhas-ingin-rakyat-pun-bisa-berpelukanserupa-jokowi-prabowo access on April 1st 2019, Time 15:03 WIB.

In-depth interviews (FGD) of 5 people conducted on April 8th 2019. 